\title{
Small seed bank in grasslands and tree plantations in former grassland sites in the South Brazilian highlands
}

\author{
Mariana de Souza Vieira (D) | Gerhard Ernst Overbeck
}

Laboratório de Estudos em Vegetação Campestre, Programa de Pós-Graduação em Botânica, Universidade Federal do Rio Grande do Sul, Porto Alegre, Brazil

\section{Correspondence \\ Mariana de Souza Vieira, Laboratório de Estudos em Vegetação Campestre, Programa de Pós-Graduação em Botânica, Universidade Federal do Rio Grande do Sul, Porto Alegre, Brazil. \\ Email: marianasvbio@gmail.com \\ Funding information \\ Conselho Nacional de Desenvolvimento Científico e Tecnológico, Grant/ \\ Award Number: 310022/2015-0 and \\ 310345/2018-9}

Associate Editor: Jennifer Powers Handling Editor: Mahesh Sankaran

\begin{abstract}
The soil seed bank can be an important source for vegetation regeneration, and data on the similarity between aboveground vegetation and the seed bank can provide information about successional pathways after disturbances or land-use change. We conducted this study in natural grasslands in the subtropical highland region in southern Brazil. We evaluated the effect of silviculture on richness, density, and composition of the seed bank at former grassland sites converted to pine plantations 25 years ago. We worked at six grassland sites and three pine plantation sites and used the seedling emergence method. Seed bank density and richness in grasslands were lower than those reported in similar environments in other regions. Species richness and density varied considerably within each vegetation type; therefore, richness and density were not statistically significant, while composition varied among vegetation types. In terms of species, the pine plantation seed bank was a small subset of the grassland seed bank. Seeds of typical grassland species were missing in the pine plantation, but also had only low abundances in the grassland, and similarity of seed bank and vegetation were low (less than $20 \%$ ). The low seed density found in this study, including in grasslands areas, indicates that regeneration of species from the soil seed bank likely is of a limited role for the maintenance of plant populations after disturbances in this system. Our data further suggest that natural regeneration after tree planting in grasslands is reduced due to seed limitation.

Abstract in Portuguese is available with online material
\end{abstract}

\section{KEYWORDS}

Atlantic forest, Pine plantation, restoration, seed limitation

\section{1 | INTRODUCTION}

Tree plantations currently cover about 264 million ha of the planet, with an annual increase of 5 million ha (data from 2000 to 2010; FAO, 2010). In developing countries, tree plantations are one of the main forms of land use (Zhang, Zhang, \& Yang, 2014), and in many cases, policy stimulates their expansion. This includes tree planting where they did not occur historically (afforestation), principally using species with high commercial value. Carbon sequestration is often used as an argument in favor of tree plantings; however, there are negative effects on other ecosystem processes and services. Among the consequence of tree plantings in regions where non-forest ecosystems dominate are loss of habitat and disruption or changes of biological processes such as nutrient cycling (Berthrong, Jobbágy, \& Jackson, 2009), hydrological cycles (Jackson et al., 2005), and changes in biodiversity (Bremer \& Farley, 2010). 
In southeastern South America, the expansion of tree monocultures, principally of Pinus spp. and Eucalyptus spp., started in the late 1980s (Gautreau \& Vélez-Martin, 2011). In South Brazil, pine is planted principally in the highland grassland region located at the southern tip of the Atlantic Forest domain. Considered old growth grasslands (sensu Veldman et al., 2015), these grasslands present high endemism levels ( $25 \%$ of the original flora; Iganci, Heiden, Miotto, \& Pennington, 2011) and high plant diversity (Andrade, Bonilha, Ferreira, Boldrini, \& Overbeck, 2016). They are traditionally used for extensive livestock grazing with rather low stocking rates, and disturbances such as fire, often used as a management tool, and grazing are responsible for maintenance of the grasslands and their biodiversity (e.g., Andrade et al., 2015).

In the past 25 years, public policies have stimulated the planting of exotic tree species in the region, although several pine species are widely known as invasive (Gautreau \& Vélez-Martin, 2011). Hermann, Lang, Gonçalves, and Hasenack (2016) assessed land-use changes in part of the highland region where our study was conducted: their study revealed an expansion of $94 \%$ in silviculture occupation in the period from 2003 to 2009. However, either for economic reasons or due to legal requirements (e.g., planting had been conducted in areas with restrictions due to conservation purposes), some of these areas are abandoned after clear cutting, including areas in or close to protected areas. The remaining flora in the soil as well the paths of the regeneration trajectory of these grasslands converted into silviculture remains unknown. Studies on restoration techniques in the South Brazilian region are recent and few (Overbeck et al., 2013; Overbeck \& Müller, 2017; Thomas, Schüler, et al., 2019), and consequently, little data are available on restoration success, or even potential for spontaneous recovery.

At plantation sites, shading by trees, along with other changes, for example, in soil properties, over several years lead to virtually complete suppression of local plant communities (Galloway, Holmes, Gaertner, \& Esler, 2017). Only a small number of species can persist over time under these conditions. Natural recovery of vegetation after clear cutting, at the end of use of the area as plantation, depends on the soil seed bank and on the dispersal of native species into the degraded area, in interaction with abiotic factors, such as soil properties (Torchelsen, Cadenazzi, \& Overbeck, 2018). Potentially, the seed bank can be an important source for vegetation regeneration and may play a key role in the assembly process of the community (Marteinsdóttir, 2014). Data on the similarity between aboveground vegetation and the seed bank can provide information about successional pathways after abandonment (Loydi, Zalba, \& Distel, 2012) and can serve as a prognostic tool to infer the early stages of colonization and to assist in planning actions for restoration. The available studies on the seed bank of subtropical grasslands in South America (e.g., Favreto \& Medeiros, 2006; Haretche \& Rodríguez, 2006; Lipoma, Funes, \& Díaz, 2018; Maia, Medeiros, Pillar, \& Focht, 2003; Vieira, Bonilha, Boldrini, \& Overbeck, 2015) indicate, in general, the presence of large seed banks in both primary and secondary grasslands. They also indicate a clear pattern of dominance of ruderal and annual species in areas with a history of intensive land use, generating differences in composition with preserved grassland areas. However, no studies exist so far for the highland grasslands of the Atlantic Forest domain of southern Brazil, which are different from Pampa grasslands in terms of climate, soil, and species composition (Andrade et al., 2019). Also, the effect of tree plantations on the seed bank of grassland has also not been evaluated so far for South American subtropical grasslands in general, and studies in other tropical and subtropical grassland regions around the world still are scarce (e.g., Galloway et al., 2017).

Here, we evaluate the soil seed bank of natural subtropical grasslands as well as that of former grassland sites now under pine plantations. Our study thus aims to contribute to the knowledge on dynamics of grassland systems in the region and to a better understanding of the effect of pine plantations on the soil seed bank and thus post-plantation vegetation recovery. Specifically, we (a) characterize, for the first time, the seed bank of natural grasslands in the South Brazilian highland grassland region in terms of richness, density, and composition; (b) evaluate the effect of tree plantation on richness, density, and composition of the seed bank in converted grassland area, in comparison with not converted grassland, and (c) relate the seed bank composition in tree plantations and natural grasslands areas to aboveground grassland vegetation and discuss the potential contribution of the seed bank for vegetation recovery.

\section{METHODS}

\section{1 | Study area}

Our study sites are located in the highland grassland region in the southern part of Brazil's Atlantic Forest domain (2904'12" S, $\left.50^{\circ} 00^{\prime} 49^{\prime \prime} \mathrm{W}\right)$. Regional climate is Cfb according to Köppen climate classification, and altitude approximately $1,000 \mathrm{~m}$. Mean annual temperature is $15^{\circ} \mathrm{C}$ and mean annual precipitation is $1,881 \mathrm{~mm}$ (climate-data.org). The region is a plateau formed by basalt, rhyolite, and rhyodacit rocks of Serra Geral Formation. Soils are classified as cambisoils according to FAO, 1997 (Cambissolos in the Brazilian classification; Embrapa 2013). Natural vegetation in the region is composed of mosaics of Araucaria forest, cloud forest, and grasslands (Leite \& Klein, 1990). These highland grasslands have been used for livestock grazing since European colonization. However, the presence of large herbivores-today extinct-even before the arrival of native American people is confirmed by the fossil record in the region (Scherer, Fedrigolo, Ribeiro, \& Guerra, 2007). Based on charcoal records from peat bogs, we know that fire has been rare during the Glacial maximum but became more frequent at the beginning of the Holocene (Behling \& Pillar, 2006). Today, fire, usually every other year, is used as a management tool to remove accumulated biomass to stimulate young leaf regrowth after winter. In terms of their floristic composition, the highland grasslands are dominated by $\mathrm{C} 4$ tussock grasses such as Andropogon lateralis Nees, Sorgastrum scaberrimum (Nees) Herter, Axonopus pellitus (Nees ex Trin.) Hitchc. $\&$ Chase and a high representation of Fabaceae family (Andrade 
et al., 2019). The region encompasses two important national parks, Aparados da Serra and Serra Geral, and other state and private protected areas. In the region, we find vast areas of pine plantations, with single planting cycles of 30 years on average, causing loss and fragmentation of natural areas (Hermann et al., 2016).

For this study, we chose six well-conserved grasslands, four located in Serra Geral National Park and two in Aparados da Serra National Park (Figure 1), and three pine plantations established in former grasslands areas. Two of them were in the buffer zone of the National parks, and one of them at the edge of the park. Pine plantations were initiated about 25 years ago. Sites were situated in three blocks, each with one pine plantation and two natural grassland areas, with the same history and similar floristic composition of grasslands. Distance of blocks varied from 2 to $20 \mathrm{~km}$, and areas within each block had distances of 500 to 2,000 m (see Figure 1 for scheme of study design).

\section{2 | Vegetation sampling}

Quantitative vegetation sampling at the grassland sites was conducted in December 2014, in 10 plots of $1 \mathrm{~m}^{2}$, randomly allocated, per grassland area. Distance between plots was approx. $50 \mathrm{~m}$. Cover of all vascular species was recorded using the Londo decimal scale (Londo, 1976). In the pine plantation areas, no vegetation survey was conducted, as ground layer vegetation was completely absent.

\subsection{Seed bank sampling and assessment}

The seed bank study was carried out using the seedling emergence method, which evaluates only the viable seeds in the soil (Thompson \& Grime, 1979). Soil samples for the seed bank study were collected in grasslands and current pine plantations. Samples were collected in two seasons (spring and autumn) with the intention of accessing both the transient seed bank and persistent seed bank (Thompson \& Grime, 1979). We used five sampling points in each study area, totaling 30 samples from grassland and 15 from pine plantations (five per area). Distances between sampling points were approximately $50 \mathrm{~m}$. Soil samples were collected with an auger (diameter: $5 \mathrm{~cm}$; depth: $10 \mathrm{~cm}$ ). At each sample point, we collected four sub-samples which were mixed, resulting in one composite sample per point. All sample points were randomly selected.

For seedling emergence, we used $50 \%$ of the soil collected in the field. Soil was mixed with vermiculite (50:50), to maintain humidity, and spread in trays (soil depth: 2-3 cm). Samples were kept in a greenhouse with irrigation for one year and were monitored weekly. Trays with sterilized soil were distributed among the soil samples from the grasslands to control possible contaminations by plants dispersed close to the experimental facilities. Emerging seedlings were identified, counted, and removed as soon as possible. For species that could not be identified right away, at least one specimen was transplanted into a larger container for development of the reproductive phase, for later identification. Most taxa (83\%) were identified to the species level and $92 \%$ to the genera level. Some individuals died in the trays or transplanted pots before identification was possible, or there was little development of individuals impeding identification.

\section{4 | Data analysis}

Data of seeds per sampling point unit were converted to density (seeds per square meter) with the aim of facilitating comparison with other studies. We averaged seed density data from the two seasons together for each sampling point. For statistical analysis, mean values of each studied area were considered, resulting in six average values for the grassland areas and three average values for the Pinus areas. For all analyses, we used randomization tests, with 10.000 iterations. This method (also referred to as permutation test), based on resampling, is also adequate for multivariate data sets, such as compositional data, and has been proposed specifically for vegetation data (details in Pillar \& Orlóci, 1996). Another advantage is that it does not require normal distribution of data, while preventing robust test results (Pillar \& Orlóci, 1996); this also makes the method especially appropriate for our data set. For analysis of richness and density data, we used Euclidean distance as dissimilarity measure and for analysis of the seed bank composition chord distance as dissimilarity measure. We analyzed composition similarities among pine plantations soil seed bank, grassland seed bank, and aboveground vegetation on grassland areas with Sørensen's Index $(2 a / 2 a+b+c)$, where $a=$ number of species common to both seed banks, $b=$ number of species unique to the first seed bank, and c = number of species unique to the second seed bank, considering all the data set of the seed bank (two seasons). Principal coordinate analysis was conducted to visualize difference in seed bank composition between the grasslands and pine plantations, using chord distance as the similarity measure. For all analyses, we used the software MULTIV (Pillar, 2006). We used alpha $=0.05$ as significance level.

\section{3 | RESULTS}

\subsection{Aboveground vegetation and soil seed bank composition}

A total of 178 species were recorded in this study. Of these, 160 species from 31 botanical families were recorded in the established vegetation on natural grasslands. The most abundant species in established vegetation were the grasses Andropogon lateralis (21\%; cover mean value across sites), Sorghastrum scaberrimum (12.8\%), and Axonopus pellitus (7.5\%), and only two exotic species (Centella asiatica and Paronychia chilensis), both considered naturalized in the region, were found. Overall, these results indicate a good conservation status of the grasslands (see Table S1 for complete species list). In the grassland soil seed bank, 45 species from twelve botanical 

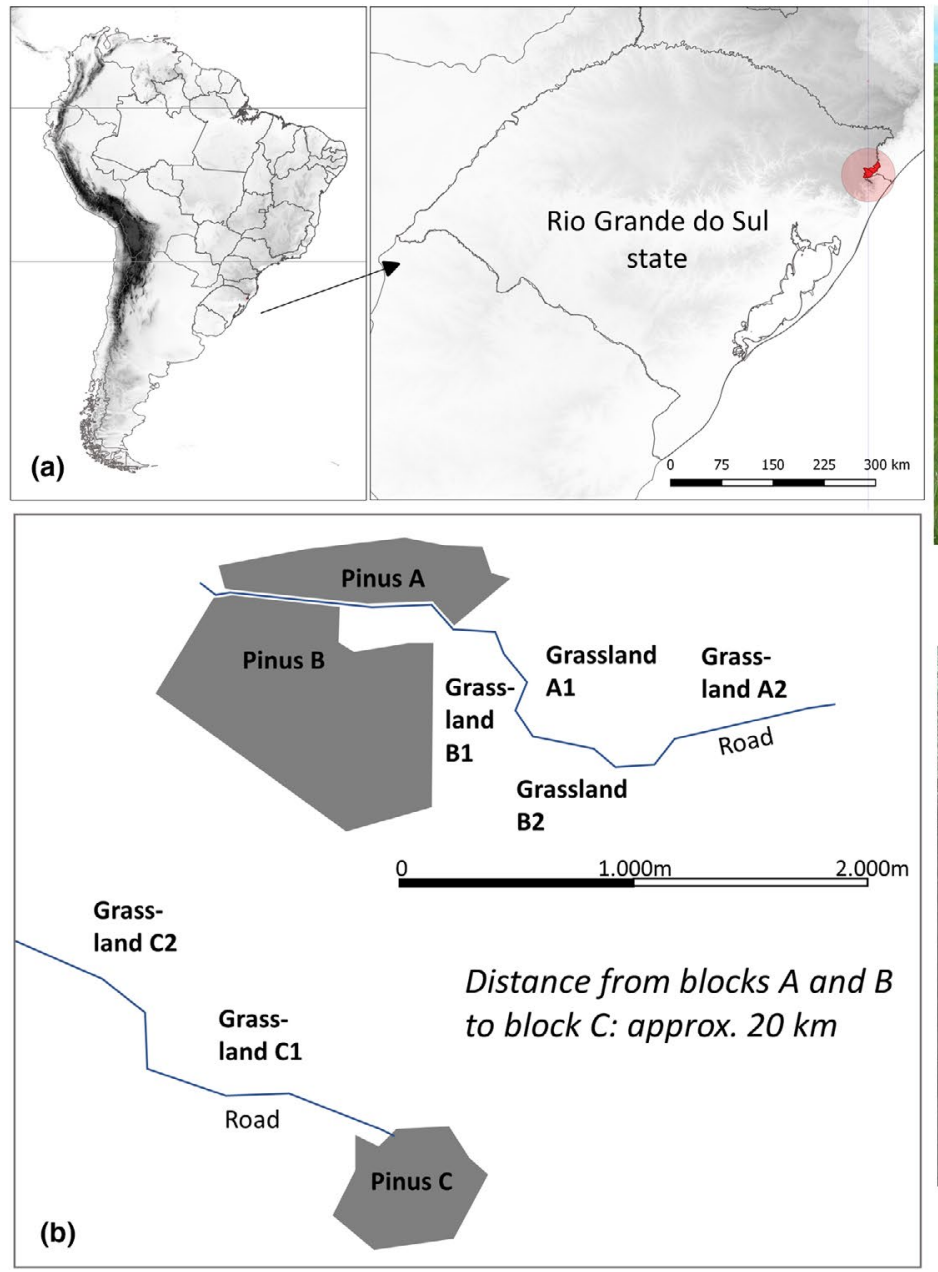
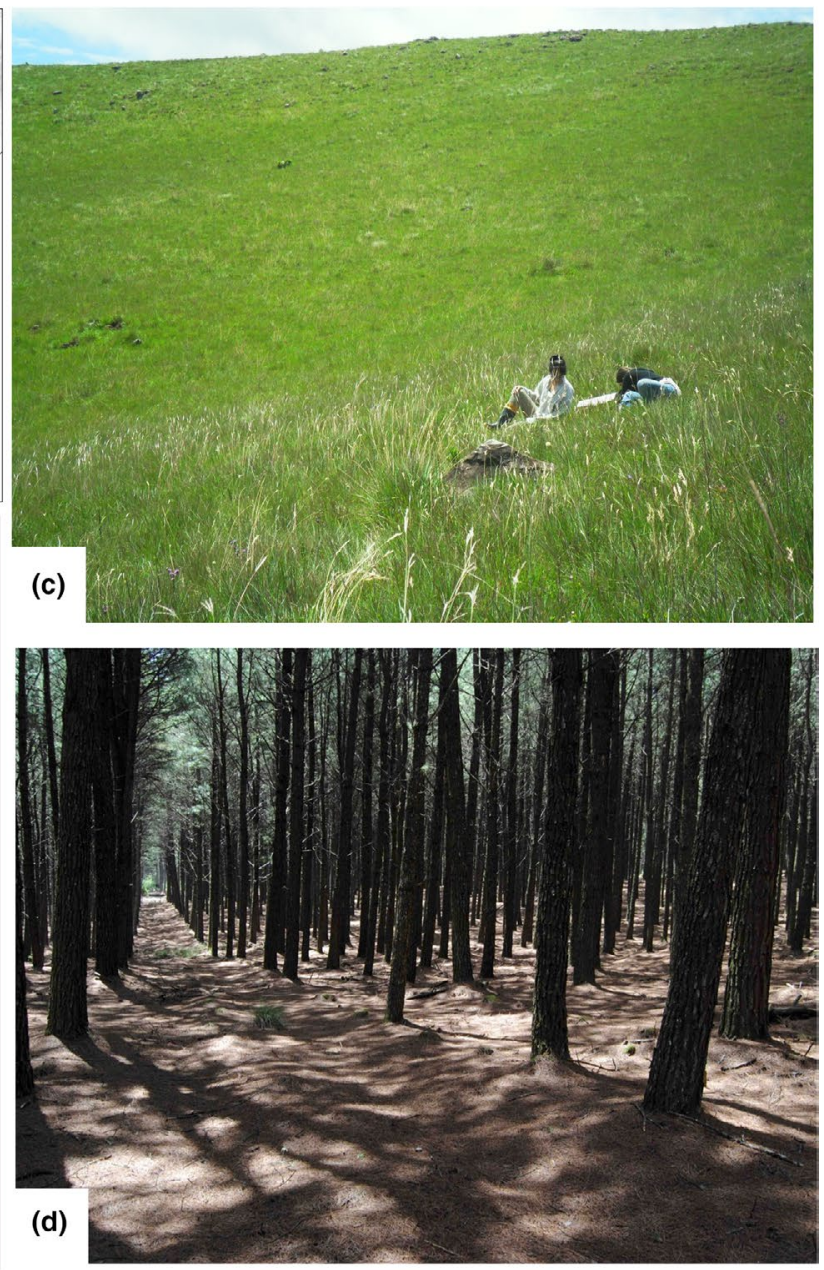

FIG URE 1 Location of the study areas. (a) Location of National Parks Aparados da Serra and Serra Geral in Brazil and Rio Grande do Sul state. (b) Schematic representation of the study sites. (c) Picture of one of the natural grasslands. (d) Picture of one of the pine plantations

families were recorded. Only 13 species, from five families, were sampled in the seed bank under pine plantation. The main families in established vegetation in the grassland areas were Poaceae (with $68 \%$ of the total plant cover), Asteraceae (12\%), and Cyperaceae (7\%), following the general pattern for grasslands of southern Brazil (Boldrini, 1997). However, this pattern changed in the seed bank. The grassland seed bank was composed of Poaceae (30\% of seed bank density), followed by Cyperaceae (22\%), Rubiaceae (20\%), and Araliaceae (14\%). In the pine plantation, where there was no established herbaceous vegetation, $51 \%$ of the seed bank density was by Cyperaceae, followed by Caryophyllaceae (23\%), Poaceae (13\%), and Rubiaceae (9\%). In terms of species richness per area, grassland seed bank and pine plantation seed bank did not differ $(p=.202)$, presenting an average of 4.4 species $/ \mathrm{m}^{2}$ (SD 3.7) in grassland seed bank compared to 1.6 species $/ \mathrm{m}^{2}$ (SD 0.8) in pine seed bank. However, the two seed banks differed in terms of composition $(p=.002)$, see Table S2.

Principal species likewise differed between established vegetation and both types of the soil seed bank. Tussock grasses principally composed the established vegetation. In contrast, the species with highest density in the grassland seed bank were Galium humile (390.5 seeds $/ \mathrm{m}^{2}$ ), Hydrocotile exigua (339.5 seeds $/ \mathrm{m}^{2}$ ), and Axonopus pellitus $\left(178.2\right.$ seeds $\left./ \mathrm{m}^{2}\right)$. The most abundant species in the pine seed bank were Bulbostylis brevifolia (237.7 seed $/ \mathrm{m}^{2}$ ), Paronychia chilensis (203.7 seeds $\left./ \mathrm{m}^{2}\right)$, Bulbostylis hirtella, Galium humile, and Dichanthelium sabulorum (each with 85 seeds $/ \mathrm{m}^{2}$ ). Mean seed density in the grassland seed bank was 2,487 seeds $/ \mathrm{m}^{2}$ (SD 2,246) and only 900 seeds $/ \mathrm{m}^{2}$ (SD 561 ) in the pine plantation seed bank; however, the differences were not significant $(p=.241)$ due to large spatial heterogeneity of the seed bank (Figure 2, based on individual sampling points to better show this variation; Suppl. Mat 1 for results of statistical analyses).

\section{2 | Similarities among established vegetation and seed banks}

In total, only seven species were shared among grassland vegetation, grassland seed bank, and pine plantation seed bank (Figure 3). Of the 160 species present in the established vegetation, 27 were also recorded in the grassland seed bank, and only eight in the soil 


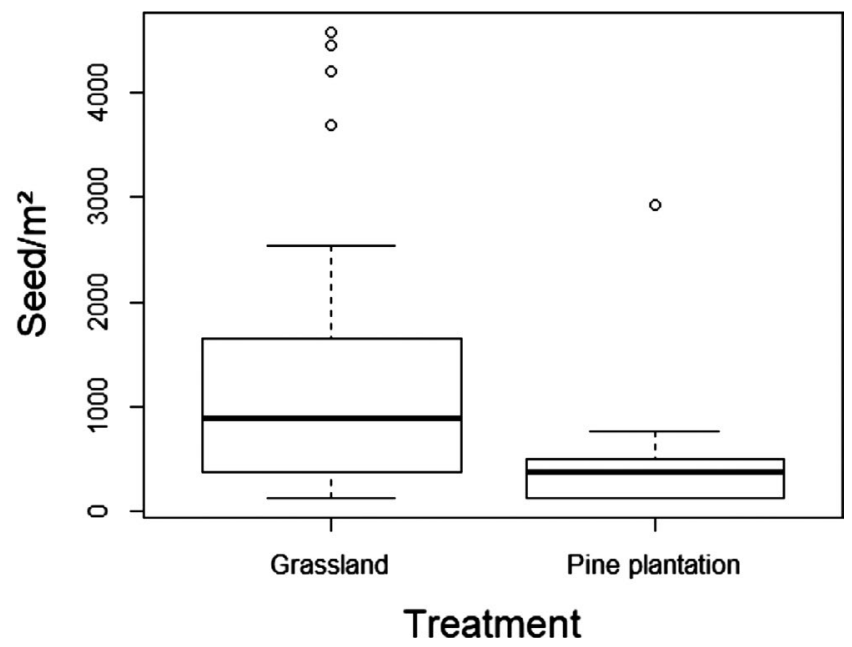

FIGURE 2 Soil seed density in a natural grassland and under pine plantation in highland grasslands in Rio Grande do Sul, Brazil. To better illustrate the high variability in seed distribution in the figure, we used sampling point data (30 sampling units for natural grassland; 15 for pine plantations), not average values per area (i.e., 5 points per area, as used for statistical analysis). Each box represents the interquartile range of the data (25\%-75\%). Dark middle bar refers to median, whiskers represent the minimum and maximum values, and dot symbols identify outliers

seed bank under pine plantations. Only one species present in the soil seed bank of the plantation areas, Paspalum plicatulum Michx, was not registered in the soil seed bank of the reference areas. No species were recorded as exclusive in the soil seed bank in the pine plantations area. The Sørensen index showed a rather high similarity between both seed banks (0.41), followed by a lower similarity between the grassland seed bank and established vegetation (0.25) and a very low similarity between established vegetation and pine plantation seed bank (0.09). The Principal coordinates analysis using the seed bank data (Figure 4) did not indicate a clear separation between areas.

\section{4 | DISCUSSION}

Our study characterized, for the first time, the seed bank of South Brazilian highland grasslands in terms of composition and density and investigated the influence of tree plantation on the soil seed bank 25 years after land-use change. While the statistical analysis did not reveal significant differences between grassland and pine plantation sites with respect to seed density and species richness, the composition data clearly indicate that typical grassland species are missing in the pine plantation seed bank that differed significantly from the grassland seed bank in terms of composition. These results differ from those of Galloway et al. (2017) in the Fynbos Biome, where the difference between reference area and 30-year-old plantations areas was low. In our study, seeds that persist in soils after a long period of conversion are largely ruderal species with little or no representation in the aboveground vegetation in the highland grasslands

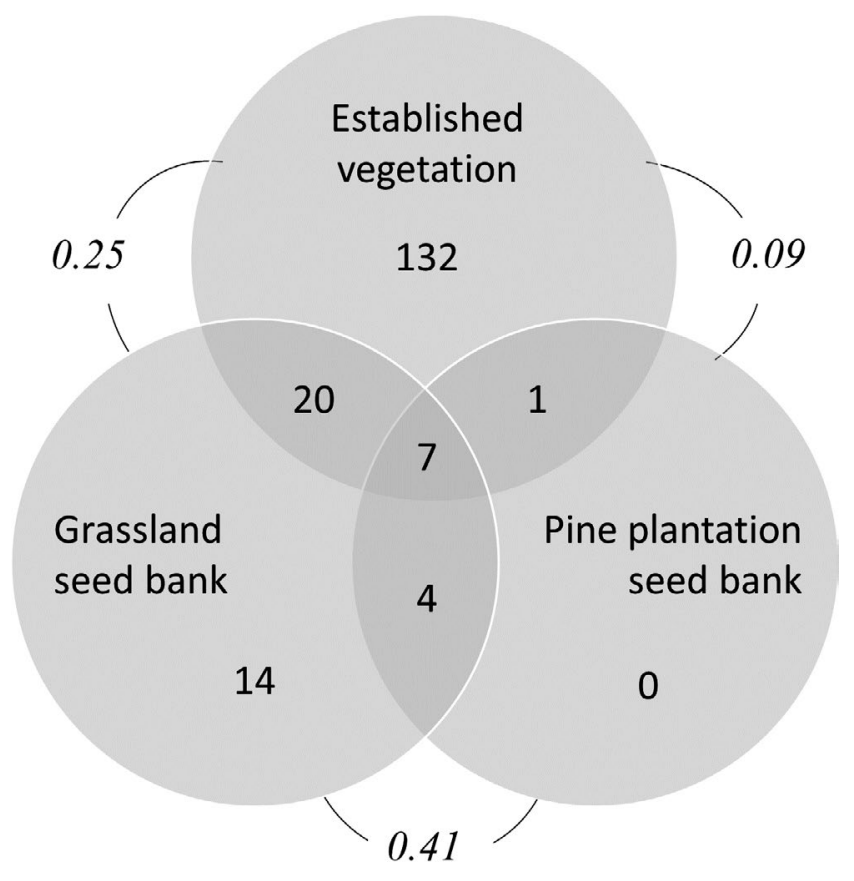

FIGURE 3 Venn diagram illustrating the number of exclusive and common species among established vegetation, grassland seed bank, and pine plantation seed bank. Numbers in italics indicate of the Sørensen similarity index, in grassland and afforestation areas in Cambará do Sul, Rio Grande do Sul, Brazil

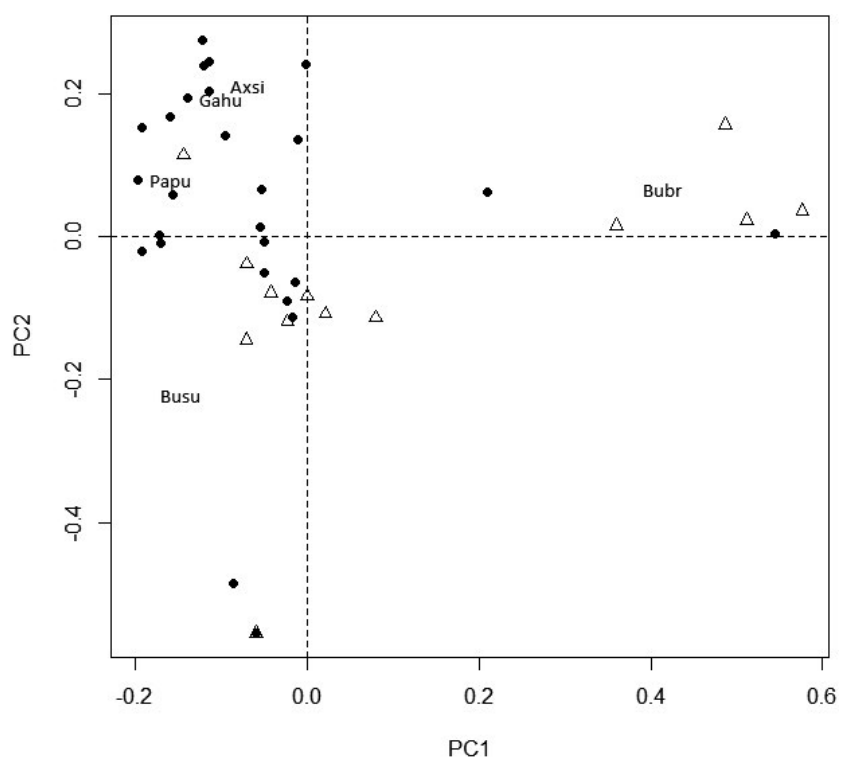

FIGURE 4 Ordination diagram (Principal Coordinates Analysis) of seed bank composition of natural areas (dots) and pine plantations (triangles) in Cambará, RS, Brazil, based on the data from the sampling points. Four points in the natural grasslands and 2 points in the pine plantations did not present any germinated seeds, therefore $n=26$ and $n=13$ for grassland and pine seed bank, respectively. Explanations of the first two ordination axes: $11 \%$ and $9 \%$, respectively. Species correlated with the axes more than 0.2: Axonopus pellitus, Bulbostylis brevifolia (Bubr), Bulbostylis subtilis (Busu), Galium humile (Gahu), Paspalum pumilum (Papu) 
of the Atlantic Forest domain of southernmost Brazil. These findings indicate that natural recovery of the typical grassland plant community from the soil seed bank after cutting of trees likely is difficult. Typical and dominant grassland species (target species in restoration) are largely missing, indicating the reduction of regional pool of species in the seed bank, as shown in the Figure 2. This result is of high relevance from a conservation perspective in a region where silviculture has been introduced over wide areas, without consideration of consequences for biological diversity in a region rich in species and endemism (Hermann et al., 2016) or consideration of possibilities of restoration.

Seed bank richness and density in both types of communities, natural grassland and pine plantation, were low when compared with other seed bank studies that used the seedling emergence method for South American subtropical grasslands (Haretche \& Rodríguez, 2006; Lipoma et al., 2018; Maia et al., 2003; Vieira et al., 2015). In these studies, density values ranged from 2,700 to 59,500 seeds/ $\mathrm{m}^{2}$ in different soil drainage conditions, with high values under more humid conditions and after land-use changes, that is, in secondary grasslands. Our study found mean values of 2,487 seeds $/ \mathrm{m}^{2}$ for natural grasslands, even though precipitation in the region is very high, which means that conditions are quite humid. While working in one specific region, we analyzed a total of six sites, and our data thus clearly indicate that the seed bank in the highland region has a low seed density per $\mathrm{m}^{2}$ when compared to other subtropical grasslands situated further to the South. The same pattern follows for richness, with only 45 recorded species, when compared to the studies cited above, in which the lowest value of richness was 54 species and values reach 122 species.

The average seed density $\left(900\right.$ seeds $\left./ \mathrm{m}^{2}\right)$ for former pine plantations was even lower than that found by Bistreau and Mahy (2005) in pine forest on former grassland sites in Belgium, but with a similar 3:1 relation of seed bank density for grassland to forest/plantation as in our study. We recorded the presence of seeds of only 13 species in the afforested area, and many of these with a ruderal character. This, as well as the low representativeness of the Poaceae family, with presence of only two species, evidences the strong effect of afforestation on the grassland soil seed bank. Due to high density of trees in the region, plantations lead to strong shading from trees, litter accumulation, soil compaction, and changes in soil-water availability; conditions that are unfavorable for maintenance of local vegetation (Roig, Río, Cañellas, \& Montero, 2005), and, as shown here, also of seeds in the soil. Our study shows that effects go beyond the time of the planting, also acting on the soil seed bank. The thick needle layer in pine plantations not only changes the local microclimate, but also generates a physical barrier, retaining seeds according to their size or shape in the litter layer as reported by Bueno and Baruch (2011). This also limits the input of seeds into the soil, as seeds dispersed from surrounding grasslands areas-if entering the plantation-will hardly be incorporated into the soil seed bank.

Natural grasslands in general show low similarity between seed bank composition and established vegetation (Luzuriaga, Escudero, Olano, \& Loidi, 2005; Vieira et al., 2015). Nonetheless, the consequences of afforestation on the vegetation are evidenced by even lower values of the Sørensen's index when comparing seed bank with established vegetation, due to both changes in composition and the low richness, as also shown by Bistreau and Mahy (2005) and Zhang et al. (2014). Our results indicate that the pine plantation seed bank contains a small subset of species of the grassland seed bank, composed of species that are tolerant to strong environmental filters, such as changed moisture and shading, and that should have long-term persistence. In the afforested areas, the seed bank was mainly composed of species from families that present many species with a ruderal strategy, such as Cyperaceae, that is, species with the capacity to produce a high number of durable seeds, which together with the low similarity to natural grassland-evaluated through the Sørensen index-indicates that the seed bank does not support the regeneration of the original plant community.

It is known that most grassland species have seeds with shortterm persistence in the soil or only produce small amounts of viable seeds (Bekker, Bakker, Grandin, \& Poschlod, 1998; Maccherini $\&$ De Dominicis, 2003). In many environments, clonal growth and vegetative reproduction offer ecological advantages, such as high competitiveness and rapid spread (Barrett, 2015). In the case of the highland grasslands of the Atlantic Forest biome of southern Brazil, which are composed principally by perennial species and are historically under disturbances as fire and grazing, most species can resprout from above- and belowground buds after disturbance (Fidelis, Appezzato-Da-Glória, Pillar, \& Pfadenhauer, 2014; Overbeck \& Pfadenhauer, 2007). The importance of these organs for vegetation recovery was also observed by Lipoma et al. (2018) in a semi-arid shrubland in Argentina with a history of burns and can be considered as analogous to that of the seed bank, which justifies the use of the term bud bank (Klimešová \& Klimeš, 2007). However, further studies that address why these grasslands have such small seed banks are needed: Has grassland management, including the use of fire, led to the selection of species that depend more on resprouting, but less on the soil seed bank? Is the small seed bank an intrinsic feature of this system? What is the role of the soil seed bank in vegetation dynamics over time? These questions still cannot be clearly answered for grasslands in our study region, nor for most other tropical and subtropical grassland regions.

\section{5 | CONCLUSIONS}

The old growth grasslands in the highland region of the southern part of Brazil's Atlantic Forest biome are under threat of biodiversity loss due to the expansion of afforestation. Our study indicated that-due to the low seed density and prevalence of sprouting species in these natural grasslands-recovery of the vegetation from the soil seed bank likely is not effective. Indeed, even in well-conserved grasslands, species likely depend much more on underground structures than on seeds for maintenance of their populations. The seed bank of the highland grasslands of southernmost Brazil studied here is much smaller than that reported for other subtropical grasslands, 
and likely, seed banks play little or no part in the regeneration of vegetation after a disturbance. Based on our findings, we can expect that active restoration with seed introduction will be necessary for restoration of grassland sites after use of pine plantations, and research on this is urgently needed if biodiversity losses in the region are to be reduced.

\section{ACKNOWLEDGMENTS}

We are grateful to CNPQ funding (477618/2013-8), CAPES for the doctoral fellowship of the first author and to the colleagues who helped in fieldwork and with species identification. We thank the staff at Aparados da Serra and Serra Geral National park and landowners for permitting this study and their help. We thank two anonymous reviewers for their comments on an earlier version of the manuscript. G.E.O. received support by CNPq (310022/2015-0 and 310345/2018-9). This study was financed in part by the Coordenação de Aperfeiçoamento de Pessoal de Nível SuperiorBrasil (CAPES)-Finance Code 001.

\section{DATA AVAILABILITY STATEMENT}

Data available from the Dryad Digital Repository: https://doi. org/10.5061/dryad.n2z34tmsw (Vieira \& Overbeck., 2020).

\section{ORCID}

Mariana de Souza Vieira (iD https://orcid. org/0000-0002-8996-728X

Gerhard Ernst Overbeck iD https://orcid. org/0000-0002-8716-5136

\section{REFERENCES}

Andrade, B. O., Bonilha, C. L., Ferreira, P. M. A., Boldrini, I. I., \& Overbeck, G. E. (2016). Highland grasslands at the southern tip of the atlantic forest biome: Management options and conservation challenges. Oecologia Australis, 20, 37-61.

Andrade, B. O., Bonilha, C. L., Overbeck, G. E., Vélez-Martin, E., Rolim, R. G., Bordignon, S. A. L., ... Boldrini, I. I. (2019). Classification of South Brazilian grasslands: Implications for conservation. Applied Vegetation Science, 22, 168-184.

Andrade, B. O., Koch, C., Boldrini, I. I., Vélez-Martin, E., Hasenack, H., Hermann, J., ... Overbeck, G. E. (2015). Grassland degradation and restoration: A framework of stages and thresholds illustrated by southern Brazilian grasslands. Brazilian Journal of Nature Conservation, 13, 95-104.

Barrett, S. C. H. (2015). Influences of clonality on plant sexual reproduction. Proceedings of the National Academy of Sciences, 112, 8859-8866.

Behling, H., \& Pillar, V. D. (2006). Late Quaternary vegetation, biodiversity and fire dynamics on the southern Brazilian highland and their implication for conservation and management of modern Araucaria forest and grassland ecosystems. Philosophical Transactions of the Royal Society B, 362, 243-251.

Bekker, R. M., Bakker, J. P., Grandin, U., \& Poschlod, P. (1998). Seed size, shape and vertical distribution in the soil: Indicators of seed longevity. Functional Ecology, 12, 834-842.

Berthrong, S. T., Jobbágy, E. G., \& Jackson, R. B. (2009). A global meta-analysis of soil exchangeable cations, $\mathrm{pH}$, carbon, and nitrogen with afforestation. Ecological Applications, 19, 2228-2241.

Bistreau, E., \& Mahy, G. (2005). Vegetation and seed bank in a calcareous grassland restored from a Pinus forest. Applied Vegetation Science, 8 , 167-174.
Boldrini, I. I. (1997). Campos do Rio Grande do Sul: Caracterização fisionômica e problemática ocupacional. Boletim de Instituto de Biociências, 56, 1-39.

Bremer, L. L., \& Farley, K. A. (2010). Does plantation forestry restore biodiversity or create green deserts? A synthesis of the effects of land-use transitions on plant species richness. Biodiversity and Conservation, 19, 3893-3915.

Bueno, A., \& Baruch, Z. (2011). Soil seed bank and the effect of needle litter layer on seedling emergence in a tropical pine plantation. Revista De Biologia Tropical, 59, 1071-1079.

FAO, 2010FAO (2010). Global Forest Resources Assessment 2010. Roma. Italy.

Favreto, R., \& Medeiros, R. B. (2006). Banco de sementes do solo em área agrícola sob diferentes sistemas de manejo estabelecida sobre campo natural. Revista Brasileira De Sementes, 28, 34-44.

Fidelis, A., Appezzato-Da-Glória, B., Pillar, V. D., \& Pfadenhauer, J. (2014). Does disturbance affect bud bank size and belowground structures diversity in Brazilian subtropical grasslands? Flora - Morphology, Distribution, Functional Ecology of Plants, 209, 110-116.

Galloway, A. D., Holmes, P. M., Gaertner, M., \& Esler, K. J. (2017). The impact of pine plantations on fynbos above-ground vegetation and soil seed bank composition. South African Journal of Botany, 113, 300-307.

Gautreau, P., \& Vélez-Martin, E. (2011). Strategies of environmental knowledge production facing land use changes: Insights from the Silvicultural Zoning Plan conflict in the Brazilian state of Rio Grande do Sul. Cybergeo : Revue européenne de géographie / European journal of geography. pp. (document 577). https://doi.org/10.4000/cyber geo. 24881

Haretche, F., \& Rodríguez, C. (2006). Banco de semmillas de un pastizal uruguayo bajo diferentes condiciones de pastoreo. Austral Ecology, 16, 105-113.

Hermann, J.-M., Lang, M., Gonçalves, J., \& Hasenack, H. (2016). Forestgrassland biodiversity hotspot under siege: Land conversion counteracts nature conservation. Ecosystem Health and Sustainability, 2, e01224.

Iganci, J. R. V., Heiden, G., Miotto, S. T. S., \& Pennington, R. T. (2011). Campos de Cima da Serra: The Brazilian Subtropical Highland Grasslands show an unexpected level of plant endemism. Botanical Journal of the Linnean Society, 167, 378-393.

Jackson, R. B., Jobbágy, E. G., Avissar, R., Roy, S. B., Barret, J. D., Cook, C. W., ... Murray, B. C. (2005). Trading water for carbon with biological carbon sequestration. Science, 310, 1944-1947.

Klimešová, J., \& Klimeš, L. (2007). Bud banks and their role in vegetative regeneration - A literature review and proposal for simple classification and assessment. Perspectives in Plant Ecology, Evolution and Systematics, 8, 115-129.

Leite, P. F., \& Klein, R. M. (1990). Vegetação. In Instituto Brasileiro de Geografia e Estatística (Ed.). Geografia do Brasil: Região Sul. vol 2. p. 113-150. Rio de Janeiro, Rio de Janeiro.

Lipoma, M. L., Funes, G., \& Díaz, S. (2018). Fire effects on the soil seed bank and post-fire resilience of a semi-arid shrubland in central Argentina. Austral Ecology, 43, 46-55.

Londo, G. (1976). The decimal scale for releves of permanent quadrants. Vegetatio, 33, 61-64.

Loydi, A., Zalba, S. M., \& Distel, R. A. (2012). Viable seed banks under grazing and exclosure conditions in montane mesic grasslands of Argentina. Acta Oecologica, 43, 8-15.

Luzuriaga, A. L., Escudero, A., Olano, J. M., \& Loidi, J. (2005). Regenerative role of seed banks following an intense soil disturbance. Acta Oecologica, 27, 57-66.

Maccherini, S., \& De Dominicis, V. (2003). Germinable soil seed-bank of former grassland converted to coniferous plantation. Ecological Research, 18, 739-751.

Maia, F. C., Medeiros, R. B., De Pillar, V. D., \& Focht, T. (2003). Composição, riqueza e padrão de variação do banco de sementes do 
solo em função da vegetação de um ecossistema de pastagem natural. Iheringia 1-19.

Marteinsdóttir, B. (2014). Seed rain and seed bank reveal that seed limitation strongly influences plant community assembly in grasslands. PLoS ONE, 9, e103352.

Overbeck, G. E., Hermann, J.-M., Andrade, B. O., Boldrini, I. I., Kiehl, K., Kirmer, A., ... Pillar, V. D. (2013). Restoration ecology in Brazil - Time to step out of the forest. Brazilian Journal of Nature Conservation, 11, $1-4$.

Overbeck, G. E., \& Müller, S. C. (2017). Restoration of tropical and subtropical grasslands. In S. K. Allison, \& S. D. Murphy (Eds.), Routledge handbook of ecological and environmental restoration (pp. 327-339). Routledge, Abingdon: Inglaterra.

Overbeck, G. E., \& Pfadenhauer, J. (2007). Adaptive strategies in burned subtropical grassland in southern Brazil. Flora - Morphology, Distribution, Functional Ecology of Plants, 202, 27-49.

Pillar, V. D. (2006). MULTIV Software para análise multivariada, testes de aleatorização e autoreamostragem "Bootstrap". v. 2.4.2. Universidade Federal do Rio Grande do Sul, Porto Alegre.

Pillar, V. D., \& Orlóci, L. (1996). On randomization testing in vegetation science: Multifactor comparisions of relevé groups. Journal of Vegetation Science, 7, 585-592.

Roig, S., Del Río, M., Cañellas, I., \& Montero, G. (2005). Litter fall in Mediterranean Pinus pinaster Ait. stands under different thinning regimes. Forest Ecology and Management, 206, 179-190.

Scherer, C. S., Fedrigolo, J., Ribeiro, A. M., \& Guerra, C. C. (2007). Contribution to the knowledge of Hemiauchenia paradoxa (Artiodactyla, Camelidae) from the Pleistocene of southern Brazil. Revista Brasileira De Paleontologia., 10, 35-52.

Thomas, P. A., Schüler, J., Boavista, L., Torchelsen, F., Overbeck, G., \& Müller, S. (2019a). Controlling the invader Urochloa decumbens: Subsidies for ecological restoration in subtropical Campos grassland. Journal of Vegetation Science, 22, 96-104.

Thompson, K., \& Grime, J. P. (1979). Seasonal variation in the seed banks of herbaceous species in ten contrasting habitats. Journal of Ecology, 67, 893-921.
Torchelsen, F. P., Cadenazzi, M., \& Overbeck, G. E. (2018). Do subtropical grasslands recover spontaneously after afforestation? Journal of Plant Ecology, 12, 1-7.

Veldman, J. W., Buisson, E., Durigan, G., Fernandes, G. W., Le Stradic, S., Mahy, G., ... Bond, W. J. (2015). Toward an old-growth concept for grasslands, savannas, and woodlands. Frontiers in Ecology and the Environment, 13, 154-162.

Vieira, M. S., Bonilha, C. L., Boldrini, I. I., \& Overbeck, G. E. (2015). The seed bank of subtropical grasslands with contrasting land-use history in southern Brazil. Acta Botanica Brasilica, 29, 543-552.

Vieira, M. S., \& Overbeck, G. E. (2020). Data from: Small seed bank in grasslands and tree plantations in former grassland sites in the South Brazilian highlands. Dryad Digital Repository, https://doi. org/10.5061/dryad.n2z34tmsw

Zhang, D., Zhang, J., \& Yang, W. (2014). Plant and soil seed bank diversity across a range of ages of Eucalyptus grandis plantations afforested on arable lands. Plant and Soil, 376(1-2), 307-325. https://doi. org/10.1007/s11104-013-1954-z

\section{SUPPORTING INFORMATION}

Additional supporting information may be found online in the Supporting Information section.

How to cite this article: de Souza Vieira M, Overbeck GE. Small seed bank in grasslands and tree plantations in former grassland sites in the South Brazilian highlands. Biotropica. 2020;52:775-782. https://doi.org/10.1111/btp.12785 